\title{
Review \\ Geochemistry of Monazite within Carbonatite Related REE Deposits
}

\author{
Wei Chen ${ }^{1, *}$, Huang Honghui ${ }^{1}$, Tian Bai ${ }^{1}$ and Shaoyong Jiang ${ }^{1,2}$ \\ 1 State Key Laboratory of Geological Processes and Mineral Resources, Collaborative Innovation Center for \\ Exploration of Strategic Mineral Resources, China University of Geosciences, Wuhan 430074, China; \\ huihuicug@163.com (H.H.); baitian_cug@163.com (T.B.); shyjiang@nju.edu.cn (S.J.) \\ 2 State Key Laboratory for Mineral Deposits Research, Department of Earth Sciences, Nanjing University, \\ Nanjing 210093, China \\ * Correspondence: wchen@cug.edu.cn; Tel./Fax: +86-027-6788-5096
}

Received: 15 July 2017; Accepted: 7 September 2017; Published: 27 September 2017

\begin{abstract}
Approximately $>50 \%$ of global rare earth element (REE) resources are hosted by carbonatite related deposits, of which monazite is one of the most important REE minerals. Monazite dominates more than 30 carbonatite-related REE deposits around the world, including currently exploited mineralization at Bayan Obo and Mount Weld. These deposits are widely distributed across all continents, except Antarctica. Though rare, monazite occurs as the primary mineral in carbonatite, and mostly presents as a secondary mineral that has a strong association with apatite. It can partially or completely replace thin or thick overgrowth apatite, depending on the availability of REE. Other mineral phases that usually crystallize together with monazite include barite, fluorite, xenotime, sulfide, and quartz in a carbonate matrix (e.g., dolomite, calcite). This review of monazite geochemistry within carbonatite-related REE deposits aims to provide information regarding the use of monazite as a geochemical indicator to track the formation history of the REE deposits and also supply additional information for the beneficiation of monazite. The chemical compositions of monazite are highly variable, and Ce-monazite is the dominant solid solution in carbonatite related deposits. Most monazite displays steep fractionation from $\mathrm{La}$ to $\mathrm{Lu}$, absent of either Eu or Ce anomalies in the chondrite normalized REE plot. The other significant components are huttonite and cheratite. Some rare sulfur-bearing monazite is also identified with an $\mathrm{SO}_{3}$ content up to $4 \mathrm{wt} \%$. A ${ }^{147} \mathrm{Sm} /{ }^{144} \mathrm{Nd}$ ratio with an average $\sim 0.071$ for monazite within carbonatite-related ores is similar to that of their host rocks ( 0.065), and is the lowest among all types of REE deposits. Sm/Nd variation of monazite from a single complex reflects the differentiation stage of magma, which decreases from early to late. Based on the differences of $\mathrm{Nd}$ and $\mathrm{Sr}$ abundances, Nd isotopic composition for monazite can be used to track the magma source, whereas $\mathrm{Sr}$ isotopic composition records the signatures of the fluid source. Th-(U)-Pb age determination of the secondary monazite records variable thermal or metasomatic disturbances, and careful geochronological interpretation should be brought forward combined with other lines of evidence. $\mathrm{ThO}_{2}$ is the most difficult contamination in the beneficiation of monazite, luckily, the $\mathrm{ThO}_{2}$ content of monazite within carbonatite is generally low $(<2 \mathrm{wt} \%)$.
\end{abstract}

Keywords: monazite; carbonatite; geochemistry; REE deposits

\section{Introduction}

Rare earth metals are essential ingredients for modern industry and the in development of high technology products in our daily lives. Although not as rare in nature as their name implies, economic deposits are not common and currently the global production of rare earth element (REE) comes from only two ore-deposit types [1]. Carbonatite-related deposits (e.g., Bayan Obo, Mountain Pass) provide the world's light REE (LREE) and ion adsorption clay deposits in Southern China supply 
heavy REE (HREE) [1,2]. Carbonatite, a rare igneous rock, contains the highest REE concentrations of any of the igneous rocks, and is especially enriched in LREE [3]. The three most important REE minerals in carbonatite related deposits are bastnasite, monazite, and xenotime [2], and are also the only REE bearing minerals that have been extracted on a commercial scale [4]. Monazite is similar to bastnasite as a LREE ore mineral, but with slightly more HREE [5]. Monazite, together with niobate, fluorocarbonate and apatite, serve as the most useful carbonatite indicator minerals for specialty metal exploration [6].

Monazite $\left[(\mathrm{REE}) \mathrm{PO}_{4}\right]$ is ubiquitous in granitic and many metamorphic rocks, sand beach, and is a primary and hydrothermal mineral in carbonatite. Monazite is found throughout the world in placer deposits, beach sands, and important components of carbonatite related REE deposits, such as Bayan Obo and Mount Weld. It displays a variety of chemical compositions, with enrichments in most incompatible elements such as thorium and uranium, which makes monazite a good isotopic and geochronological indicator for the genesis of these rocks. The accommodation of Th and U into the monazite crystal without sustaining damage serves it as a potential host matrix for sequestering long-lived radionuclides [7]. On the other hand, thorium and uranium abundances in monazite present a negative aspect of mining and processing [5].

Monazite is a ubiquitous accessory phase in carbonatite and form economic REE deposits; however, no systematic investigation of this mineral has been provided in carbonatite-related REE deposits. This review aims to provide a summary of monazite geochemistry in carbonatite and related alkaline rocks. Furthermore, it will contribute information for the future study of monazite, which can be used as a geochemical indicator to track the formation history and also supply additional information for the beneficiation of monazite within these REE deposits.

\section{Distribution of Monazite Dominated Carbonatite REE Deposits}

Monazite-dominated carbonatite REE deposits have been identified worldwide, and their distribution is shown in Figure 1 and summarized in Supplementary Materials Table S1. They are widely distributed across all continents except Antarctica (Figure 1). Most of the REE deposits are carbonatite-related and contain dominant bastnasite, monazite, pyrochlore, apatite, xenotime, allanite, barite, and fluorite (Supplementary Materials Table S1). Several abundant monazite deposits are associated with phoscorite-nelsonite rocks in the alkaline complex (e.g., Purulia; Hongcheon). Some carbonatite REE deposits are bastnasite dominated with monazite in the secondary abundance (e.g., Bayan Obo, Mountain Pass). Monazite is the most dominant REE mineral in supergene deposits, such as Mount Weld and Araxa. Recent reviews on rare earth element related deposits can be found in References $[2,5,6]$.

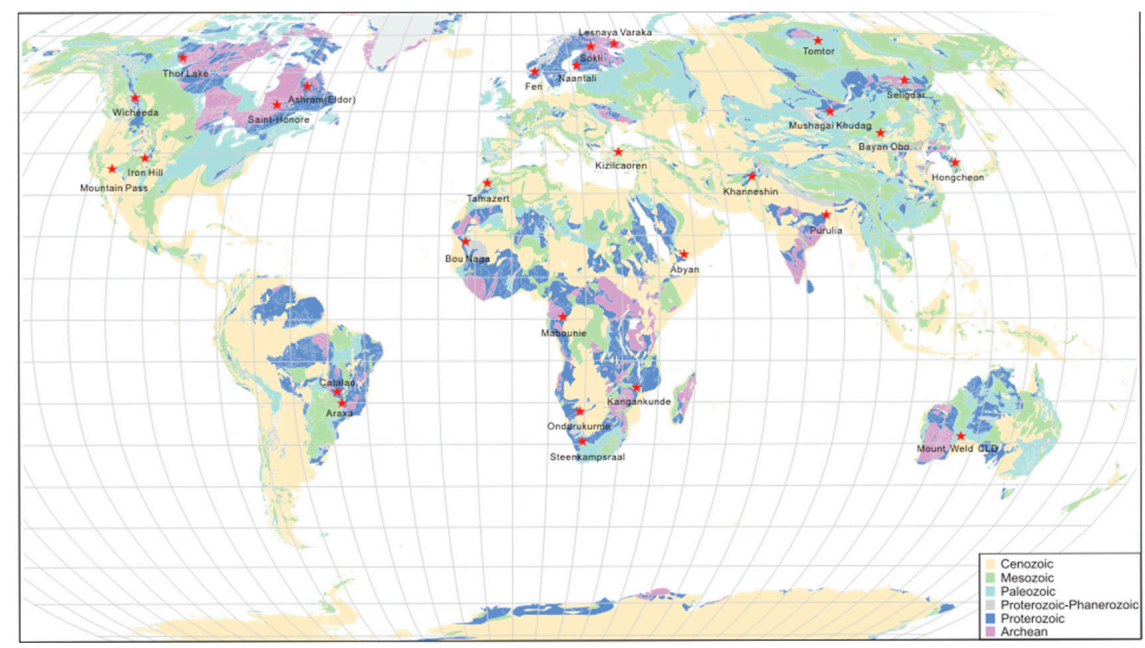

Figure 1. Geological map of the locations of monazite dominant carbonatite related REE deposits. 


\section{Texture Characteristics of Monazite}

Monazite can occur as a primary accessory mineral phase in carbonatite [8] with euhedral to subhedral grains that vary from $\sim 25$ to $\sim 200 \mu \mathrm{m}$ in size (e.g., Mountain Pass; Kangankunde Hill; Bayan Obo; Figure 2a,b). In thin sections, monazite appears in a variety of colors, from colorless to yellowish, greenish, and brownish [9,10] (e.g., Figure 2c,d). More commonly, it is the product of metasomatic/hydrothermal alteration of the primary mineral assemblage within the carbonatite (e.g., apatite) or occurs along the fractures of the matrix carbonate as interstitial fillings or form veinlets or, which appears as fine-grained polycrystalline clusters (e.g., Figure 2e,f, or Figure 3) [11]. The secondary monazite commonly shares mineral associations with apatite, barite, fluorite, hematite, quartz, sulfide, bastnasite, xenotime, feldspar, titanite, synchysite, goyazite, and strontianite. Some monazite shows an association with K-feldspar [12,13] (e.g., Figure 2h), or is intergrown with albite [9] (e.g., Evate). The monazite aggregates display a close association with molybdenite in the Huanglongpu carbonatite (Figure 2i). Different generations of monazite can be found in the same rock or a large crystal, for example, huge monazite crystals $(>1 \mathrm{~mm}$ ) in a matrix of ankerite, apatite, pyrite and quartz have been identified with a euhedral to subhedral core in the Hongcheon complex, and the surrounding small grains in the cracked and resorbed rim that possibly formed as a result of late-stage hydrothermal activities [14] (Figure 2j).

The monazite-apatite association is quite common in carbonatite related deposits. Monazite partially or completely replaces apatite, and the replaced monazite displays a cracked nature [15] (Figure 3a; e.g., Sokli monazite). Secondary monazite usually occurs as small crystals (up to $30 \mu \mathrm{m}$ in size) on the edge, replacing apatite or is included within apatite crystals (Figure 3b). Commonly, monazite occurs as small crystals or polycrystalline aggregates (up to $20 \mu \mathrm{m}$ ) at the corroded LREE-rich rims of apatite (Figure 3d). Monazite sometimes occurs together with bastnasite as inclusions in apatite (Figure 3c; e.g., Naantali carbonatite [16]). The crystal size of monazite overgrowing apatite can be both small and large (Figure $3 \mathrm{~d}-\mathrm{f})$. Some monazite grains occur as very thin layer aggregates $(<10 \mu \mathrm{m})$ surrounding apatite or so-called girdles around the coarse fluorapatite, for instance, phoscorite from the district of Purulia, India [17] (Figure 3e). Large monazite overgrown apatite has been identified in several deposits [18] (up to $2 \mathrm{~mm}$ in diameter; Figure 3f; e.g., Abyan; Bayan Obo). These secondary monazites associated with apatite might form in a scenario where hydrothermal solutions rich in REEs permeated fresh carbonatite along fractures and reacted with apatite to produce pseudomorphs of polycrystalline monazite or overgrowth on the edge of apatite [8]. Apatite associated hydrothermal monazite is common in both magmatic and metamorphic rocks (e.g., Dabie Shan clinopyroxenite [19]). In carbonatite-related deposits, monazite has rarely been observed to form in carbonatite until the end stages of apatite crystallization. Though monazite can survive at temperatures much higher than $750{ }^{\circ} \mathrm{C}$, in carbonatite it is restricted to temperatures lower than $750{ }^{\circ} \mathrm{C}$ [20]. 

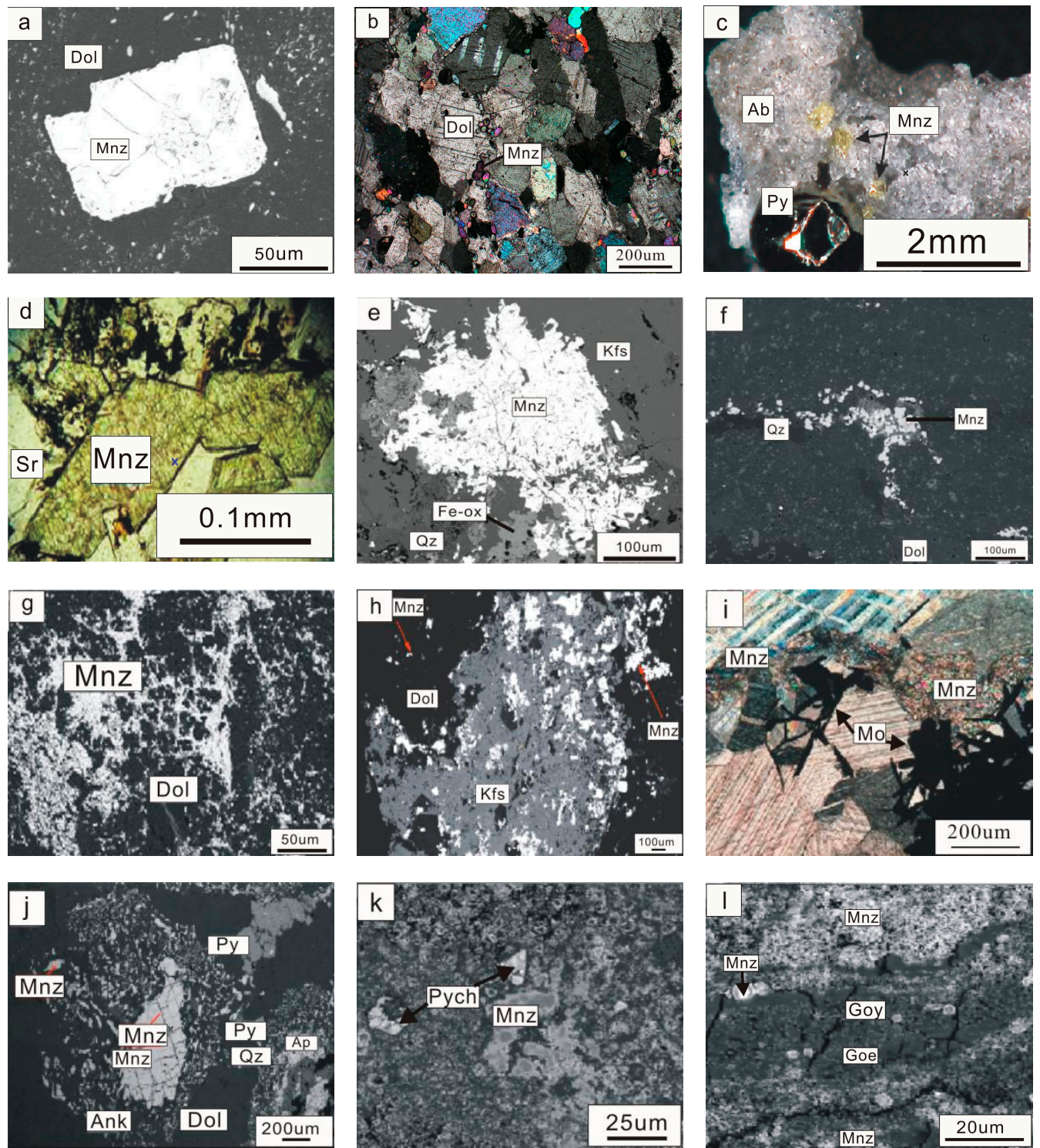

Figure 2. Petrographic images for monazite from carbonatite related REE deposits. (a) Backscattered electron (BSE) image of euhedral monazite in carbonatite from Mountain Pass, the United States [21]; (b) disseminated monazite within dolomite marble from Bayan Obo, Inner Mongolia, China; (c) yellow monazite crystals crystallized on the rim of albite matrix from Evate, Mozambique [9]; (d) green monazite occurs as disseminations in the strontianite matrix in Kangankunde, Malawi [10]; (e) BSE image of anhedral monazite in carbonatite from Mountain Pass, the United States [21]; (f) monazite in strongly foliated dolomite carbonatite with quartz laminae from the Cummins Range carbonatite, Australia [22]; (g) monazite net of veinlets in dolomite from Seligdar apatite deposit, Russia [11]; (h) backscattered electron image showing a vug in dolomite filled with potassium feldspar and monazite from the Wideeda carbonatite, Canada [12]; (i) monazite aggregates together with molybdenite in the calcite carbonatite from Huanglongpu, China; (j) euhedral monazite core with small monazite grains in the cracked and resorbed rim from the Hongcheon complex, Korea [14]; (k,1) typical monazite-pyrochlore-crandallite ore in the Tomtor deposit (Russia); and relict pyrochlore crystal in monazite and goyazite as colloform globular segregations in a colloform goethite aggregate [23]. $\mathrm{Ab}=$ albite; Ank = ankerite; $\mathrm{Ap}=$ apatite; $\mathrm{Mnz}=$ monazite; Dol = dolomite; Goe = Goethite; Goy = goyazite; Kfs = K-feldspar; Mo = Molybdenite; Py = pyrite; Pych = pyrochlore; and Qz = Quartz. 

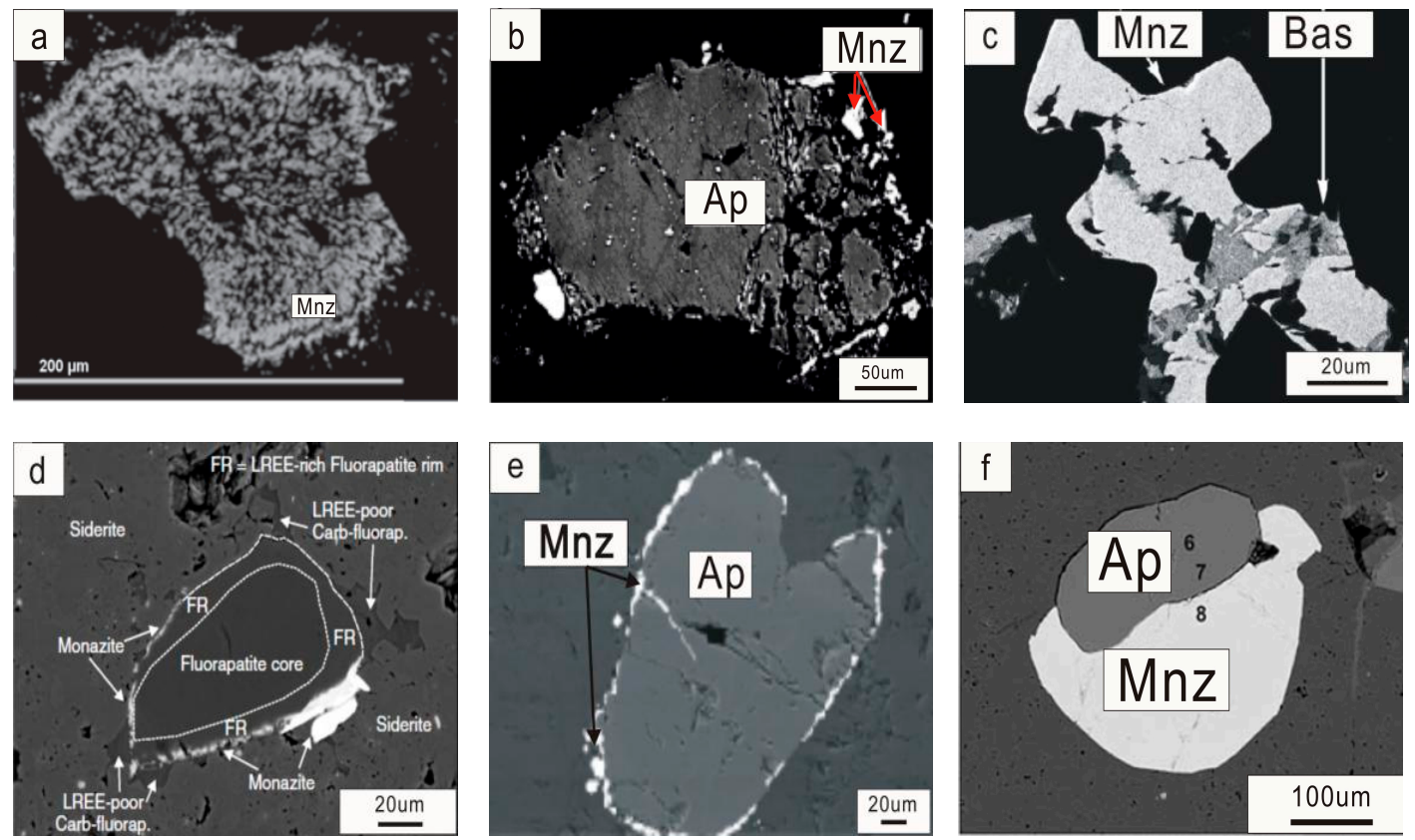

Figure 3. BSE images for monazite and apatite mineral association in carbonatite related alkaline rocks. (a) apatite grain completely replaced by monazite in carbonatite from the Sokli complex, Finland [15]; (b) monazite on the edge or included within the heterogeneous apatite in the apatite-dolomite ore from the Seligdar deposit, Russia [11]; (c) monazite inclusions within apatite in association with bastnaesite inclusions from the Naantali carbonatite, Finland [16]; (d) apatite crystal with a LREE-rich rim partly replaced and overgrown by monazite associated with LREE-poor carbonate-apatite in the Matongo carbonatite, Burundi [22]; (e) monazite grains girdling around coarse apatite in the Purulia phoscorite, India [17]; and (f) monazite overgrowth on apatite in the Abyan carbonatite, Yemen Republic [18]. Ap = apatite; Bas = bastnasite; and Mnz = monazite.

The most common supergene REE mineral in carbonatite and related alkaline rocks is monazite, and it has been found in laterite that derived from the chemical weathering of carbonatites, e.g., Mt. Weld, Australia [24]; Araxa and Catalao I, Brazil [8,25]; Tomtor, Russia [23]; Mrima Hill, Kenya [26]; Mabouni, Gabon; and several other carbonatite laterites in the Amazon region of Brazil [27]. Carbonate minerals are easily dissolved when carbonatite is subjected to chemical weathering, and $\mathrm{Ca}$ and $\mathrm{Mg}$ can be removed, leaving behind less mobile elements (e.g., REEs and Sr) [8]. Porous monazite aggregates in the carbonatite laterite from Mt. Weld contain inclusions of apatite, plumbogummite, goethite, cerianite, ilmenite, quartz, and Mn minerals [24]. Monazite spherulitic aggregates composed of hollow tubes ( $300 \mu \mathrm{m}$ in diameter), resembling biomorphic structures, have been shown in the Tomtor deposit (Figure 2k,l) [23]. Supergene monazite coexists with minerals of hydrothermal origin, e.g., barite, crandallite group minerals, and sulfides [23,25]. Halloysite in aggregates have been reported for Tomtor, also confirming hydrothermal activity. The presence of thermal waters was observed in some of the supergene monazite formation sites (e.g., Catalao I complex) [28].

\section{Chemical Compositions}

\subsection{REE Compositions}

Monazite has the nominal composition (LREE) $\mathrm{PO}_{4}$, and those within carbonatite related REE deposits usually show significant variation in chemical composition [29]. Without including the exceptions found in Lesnaya Varaka [29], the total $\mathrm{REE}_{2} \mathrm{O}_{3}$ contents within monazite range from 49.6 to $74.13 \mathrm{wt} \%$ and the average value is $64.31 \mathrm{wt} \%$ (Supplementary Materials Table S2). Depending on the dominant light rare earth element, the following varieties have been identified including 
monazite-La [30], monazite-Ce [31], and monazite-Nd [32]. Monazites formed within carbonatite related complexes are usually a Ce dominated phosphate, and the $\mathrm{Ce}_{2} \mathrm{O}_{3}$ content generally varies between 8.74 and $38.46 \mathrm{wt} \%$ with an average of $32.47 \mathrm{wt} \%$, which is much higher compared to $\mathrm{La}_{2} \mathrm{O}_{3}$ and $\mathrm{Nd}_{2} \mathrm{O}_{3}$ (Supplementary Materials Table S2; Figure 4a). $\mathrm{La}_{2} \mathrm{O}_{3}$ composition varies from 0.46 to $27.60 \mathrm{wt} \%$ in different carbonatite and related alkaline rocks, with an average value of $18.09 \mathrm{wt} \%$ (Supplementary Materials Table S2). The highest La-bearing monazite has been identified from the Abyan complex, with an average $\mathrm{La}_{2} \mathrm{O}_{3}$ content of $23.58 \mathrm{wt} \%$ [18]. The content of $\mathrm{La}_{2} \mathrm{O}_{3}$ also varies significantly in the same rock sample, depending on the crystallization stage (e.g., 15.44-21.75 wt \%; Purulia phoscorite [17]). $\mathrm{Nd}$ is less enriched in monazite compared to La, and the $\mathrm{Nd}_{2} \mathrm{O}_{3}$ composition varies from 4.38 to $17.41 \mathrm{wt} \%$ with an average of $9.43 \mathrm{wt} \%$ (Supplementary Materials Table S2). Monazite from Naantali carbonatite contains the highest $\mathrm{Nd}_{2} \mathrm{O}_{3}$ content, ranging from 14.79 to $17.38 \mathrm{wt} \%$ [16], and these display the lowest $(\mathrm{La} / \mathrm{Nd})_{\mathrm{N}}$ ratios ( 1.5; Supplementary Materials Table S2). Monazite in the highly altered rocks is depleted in $\mathrm{La}, \mathrm{Ce}$, and $\mathrm{Pr}$ when compared to those in unaltered or partially altered ferro carbonatite in the Kola carbonatite [20]. Composition variations of La and $\mathrm{Nd}$ within a single monazite have been found at Kangankunde, which display differential REE uptake by sector growth of the crystal [33]. The contents of La, Pr, and Nd have been shown to decrease from core to rim for Hongcheon monazite, whereas the compositions of $\mathrm{Ce}, \mathrm{Eu}$, and $\mathrm{Gd}$ tend to increase [34].

MREE and HREE are normally depleted in monazite compared to LREE, and not many have been reported. $\mathrm{Gd}$ and $\mathrm{Eu}$ are both the dominant MREEs in monazite. $\mathrm{A} \mathrm{Eu}_{2} \mathrm{O}_{3}$ composition of $\sim 1.1 \mathrm{wt} \%$ has been reported for Naantali monazite [16], whereas Hocheong monazite contains $0.46-0.92 \mathrm{wt} \%$ of $\mathrm{Eu}_{2} \mathrm{O}_{3}$ [34]. The latter also had the highest $\mathrm{Gd}_{2} \mathrm{O}_{3}$ content $(\sim 4 \mathrm{wt} \%)$ identified for monazite within carbonatite-related deposits [34]. These contents are higher compared to those for metamorphic monazite, of which $\mathrm{Eu}_{2} \mathrm{O}_{3}$ is generally below $0.5 \mathrm{wt} \%$ [35]. Based on these published data, MREE contents within monazite are restricted to less than $2 \mathrm{wt} \%$ and HREE abundances are even lower ( $\sim .5 \mathrm{wt} \%$; Supplementary Materials Table S2).

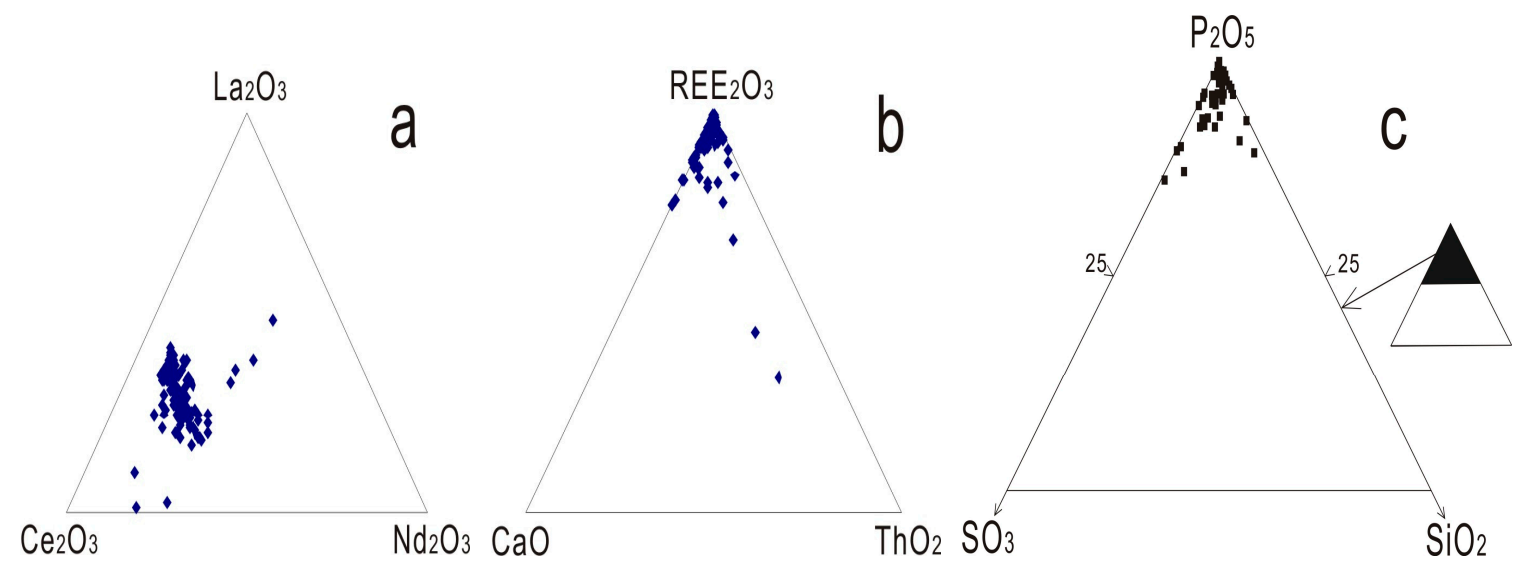

Figure 4. Compositional triplots of monazite from carbonatite related REE deposits. (a) $\mathrm{La}_{2} \mathrm{O}_{3}-\mathrm{Ce}_{2} \mathrm{O}_{3}-\mathrm{Nd}_{2} \mathrm{O}_{3}$; (b) $\mathrm{REE}_{2} \mathrm{O}_{3}-\mathrm{ThO}_{2}-\mathrm{CaO}$; and (c) $\mathrm{P}_{2} \mathrm{O}_{5}-\mathrm{SO}_{2}-\mathrm{SiO}_{2}$.

Monazite from carbonatite related deposits generally displays a straight linear trend decreasing from $\mathrm{La}$ to $\mathrm{Lu}$ in chondrite normalized REE diagrams (Figure 5a). The absence of the Ce anomaly in the REE patterns suggests reducing environments during monazite crystallization. The smooth Eu patterns are distinct for monazite formed in carbonatite related environments [34], whereas granitic monazite is commonly characterized by a positive Eu anomaly, and a negative Eu anomaly is typical for metamorphic monazite [35]. The slopes of the chondrite normalized REE profiles for monazite are shallower than those of REE minerals, such as bastnasite, ancylite and cordylite, and comparable to those of parasite and synchysite in the Wicheeda carbonatite, which suggests that monazite with parasite and synchysite are more enriched in HREEs [12]. 

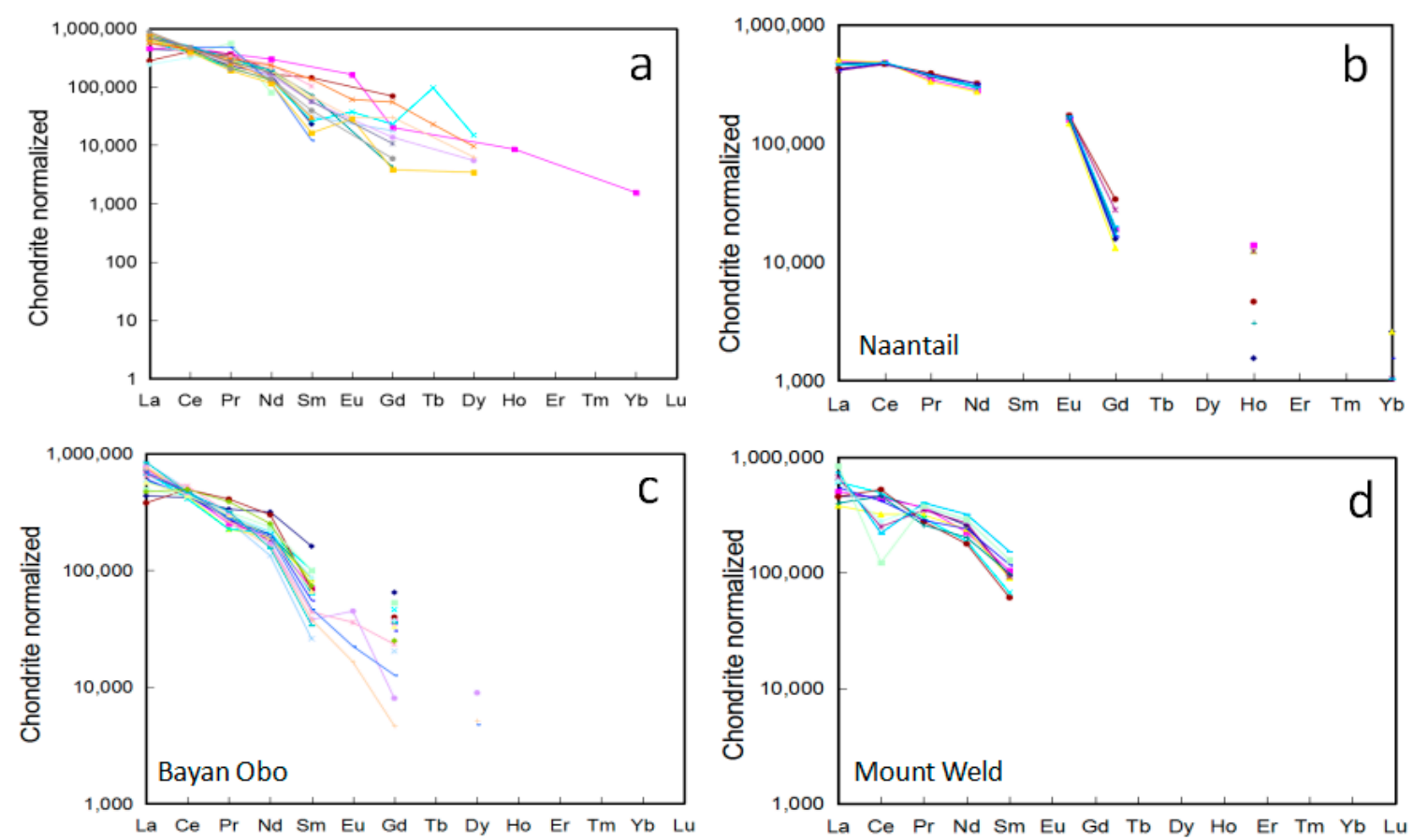

Figure 5. Chondrite normalized REE patterns for monazite from carbonatite related REE deposits. (a) all deposits; (b) Naantali; (c) Bayan Obo; and (d) Mount Weld.

The chondrite normalized REE patterns pivot about the Ce position observed for monazite from Kangankunde, Abyan, Bayan Obo, and Naantali [18,20,33,36] (Figure 5b,c). The pivot point corresponds to $\mathrm{Ce}_{2} \mathrm{O}_{3}$ contents of 31-34 wt \% (Supplementary Materials Table S2; Figure 5b,c). $\mathrm{La}$ and Ce decoupled with total LREE variations, and decreased relative to Ce (e.g., Bayan Obo; Figure 5c). Wall and Zaitsev [20] proposed that this was common among mineralized carbonatite and correlates with increasing volatile activity accompanying mineralization, with a wider range of La and $\mathrm{Nd}$ representing hydrothermal activity. Small differences in the probability of uptake distinct REE (e.g., La, Nd) onto different growth surfaces of monazite results in a pivoting effect at Ce [20]. The variations of $\mathrm{La} / \mathrm{Nd}$ ratios have been used to indicate different stages of the carbonatite evolution. As indicated by Kim et al. [34], monazite within the early-stage carbonatite at Hongcheon contains lower $\mathrm{La} / \mathrm{Nd}$ ratios (2.98-3.94) compared to those in the late-stage monazite $(\mathrm{La} / \mathrm{Nd}=3.28-4.57)$. In the magmatic-hydrothermal system, Smith et al. [37] suggested that minerals with lower La/Nd ratios formed from dominantly aqueous solutions. The chondrite normalized $\mathrm{La} / \mathrm{Nd}$ ratio varied from $\sim 3-7$ in early disseminated monazite at Bayan Obo, whereas vein-hosted monazite was characterized by ratios in the range of $\sim 4.8-5.8$ [37].

The Ce pivot point was not observed for monazite in the Mt. Weld carbonatite laterite (Figure 5d), some of the monazites display a distinct negative Ce anomaly that might correspond to crystallization in an oxidized environment. Supergene monazite during the weathering process shows higher $Y$ and MREE contents when compared to the primary monazite from the same complex [8]. In the Catalao I carbonatite complex, weathered monazite displayed a less steep REE pattern (i.e., lower $\mathrm{La} / \mathrm{Nd}$ ratio) when compared to those within carbonatite [28]. The detailed chemical compositions of monazite within carbonatite related environments can be found in Supplementary Materials Table S2 [11-14,16-18,20,23,24,29,30,34,35,37-43].

\subsection{Various Element Accommodations in Monazite}

Monazite, a LREE phosphate, also embraces various element accommodations in the crystal. Most monazite contains additional $\mathrm{Th}, \mathrm{U}, \mathrm{Ca}, \mathrm{Sr}, \mathrm{Si}$, and $\mathrm{Pb}$, and some also accommodate $\mathrm{S}$ (Figure 4b,c). 
$\mathrm{ThO}_{2}$ content in monazite from carbonatite related deposits are commonly low (e.g., <2 wt \%; Supplementary Materials Table S2) compared to those in metamorphic and sedimentary deposits [27]. Possible substitution schemes to accommodate Th in monazite include:

$$
\begin{gathered}
2 \mathrm{Ce}^{3+} \leftarrow \mathrm{Ca}^{2+}\left(\mathrm{Sr}^{2+}\right)+\mathrm{Th}^{4+} \\
\mathrm{Ce}^{3+}+\mathrm{P}^{5+} \leftarrow \mathrm{Th}^{4+}+\mathrm{Si}^{4+}
\end{gathered}
$$

The first substitution scheme represents a solid solution series between monazite $\left(\mathrm{CePO}_{4}\right)$, cheralite [CaTh $\left.\left(\mathrm{PO}_{4}\right)_{2}\right]$, and $\mathrm{SrTh}\left(\mathrm{PO}_{4}\right)_{2}$ [39], commonly known as the cheralite substitution [44,45]. Accommodation of Th in monazite may involve a coupled substitution with $\mathrm{Si}$ as listed as the second scheme, which is known as the huttonite substitution [20,44,45]. Both substitutions contribute to the accommodation of Th in Naantali monazite (with a range of 1.1-1.5 wt $\% \mathrm{ThO}_{2}$ ) though the huttonite mechanism may play the dominant role given that better correlation between $\mathrm{ThO}_{2}$ and $\mathrm{SiO}_{2}$ has been identified (Figure 6a,b) [16]. Again, both huttonite and cheralite solid substitution in monazite have been identified for the Sokli complex and the Lesnaya Varaka complex, with $\mathrm{ThO}_{2}$ content as high as $34.94 \mathrm{wt} \%$ (Figure 6c-f; Supplementary Materials Table S2) [15,23]. These monazites contain high and variable amounts of $\mathrm{SrO}$ ranging from 0.92 to $4.2 \mathrm{wt} \%$ and $\mathrm{CaO}$ contents ranging from 0.92 to $4 \mathrm{wt} \%$, which display co-substitution with Th (Figure 6e,f). The cheralite substitution mechanism may indicate selective removal of $\mathrm{Ca}$ and $\mathrm{Sr}$ from apatite in the presence of a REE-rich hydrothermal solution as well as the immobility of $\mathrm{P}$, which is indicated by the petrographic texture of monazite replacing apatite (Figure 3). $\mathrm{ThO}_{2}$ content variation has also been identified within the large crystals, for instance, those from the Abyan deposit were observed to decrease from $>2 \mathrm{wt} \%$ in the center to $<0.5 \mathrm{wt} \%$ at the rim and along the fractures [18]. The high Th content is most common in high-temperature monazite [20].

Monazite can contain appreciable $\mathrm{Si}$ and $\mathrm{S}$, with up to $2.65 \mathrm{wt} \%$ of $\mathrm{SiO}_{2}$ and $4.06 \mathrm{wt} \%$ of $\mathrm{SO}_{3}$ (Supplementary Materials Table S2; Figure 4c). The accommodation of Si is dominantly controlled by the huttonite substitution as indicated by the positive linear correlation between $\mathrm{ThO}_{2}$ and $\mathrm{SiO}_{2}$, and the negative correlation between $\mathrm{Ce}_{2} \mathrm{O}_{3}+\mathrm{P}_{2} \mathrm{O}_{5}$ and $\mathrm{ThO}_{2}+\mathrm{SiO}_{2}$ (Figure 6c,d). Appreciable $\mathrm{SO}_{3}$ contents (0.61-4.06 wt \%) have only been observed in monazite from Mushgai Khudag, Kandaguba, Vuorijarvi, and Khaluta [42,46,47] (Supplementary Materials Table S2). Furthermore, the accommodation of sulfur may be controlled by the third substitution scheme; however, it is poorly supported by the currently available data. Monazite from the Cataolo I complex consists of low $\mathrm{REE}_{2} \mathrm{O}_{3}(\sim 50 \mathrm{wt} \%)$ and $\mathrm{P}_{2} \mathrm{O}_{5}$ $(\sim 25 \mathrm{wt} \%)$ as well abundant $\mathrm{SrO}(\sim 2.6 \mathrm{wt} \%)$ and $\mathrm{CaO}(\sim 1.2 \mathrm{wt} \%)$ contents, which could also possibly contain some sulfur or thorium in the crystal; however, both sulfur and thorium were not analyzed in the dataset [28]. Different $\mathrm{SO}_{3}$ bearing domains in patchy zoned monazite crystals from the Rogaland granulite have been investigated in-situ with $\mathrm{U}-\mathrm{Th}-\mathrm{Pb}$ ages, and the results show that $\mathrm{S}$ contents in monazite could possibly be used to discriminate different generations of monazite [40].

$$
\mathrm{Ce}^{3+}+\mathrm{P}^{5+} \leftarrow \mathrm{Ca}^{2+}\left(\mathrm{Sr}^{2+}\right)+\mathrm{S}^{6+}
$$

Arsenic may substitute for $\mathrm{P}$ in monazite, though is quite rarely identified in carbonatite-related environments [48]; about 0.27-1.02 wt \% of $\mathrm{As}_{2} \mathrm{O}_{5}$ has been reported for Nataanli monazite [16]. Monazite with $\mathrm{F}$ or $\mathrm{Cl}$ may indicate the metasomatic origin of the crystal, which is a hydrothermal product from apatite (Supplementary Materials Table S2). Monazite $\left[(\mathrm{REE}) \mathrm{PO}_{4}\right]$ can also contain water in the crystal structure and becomes euhedral crystals as hexagonal (REE) $\mathrm{PO}_{4} \cdot \mathrm{nH}_{2} \mathrm{O}$ [20]. 

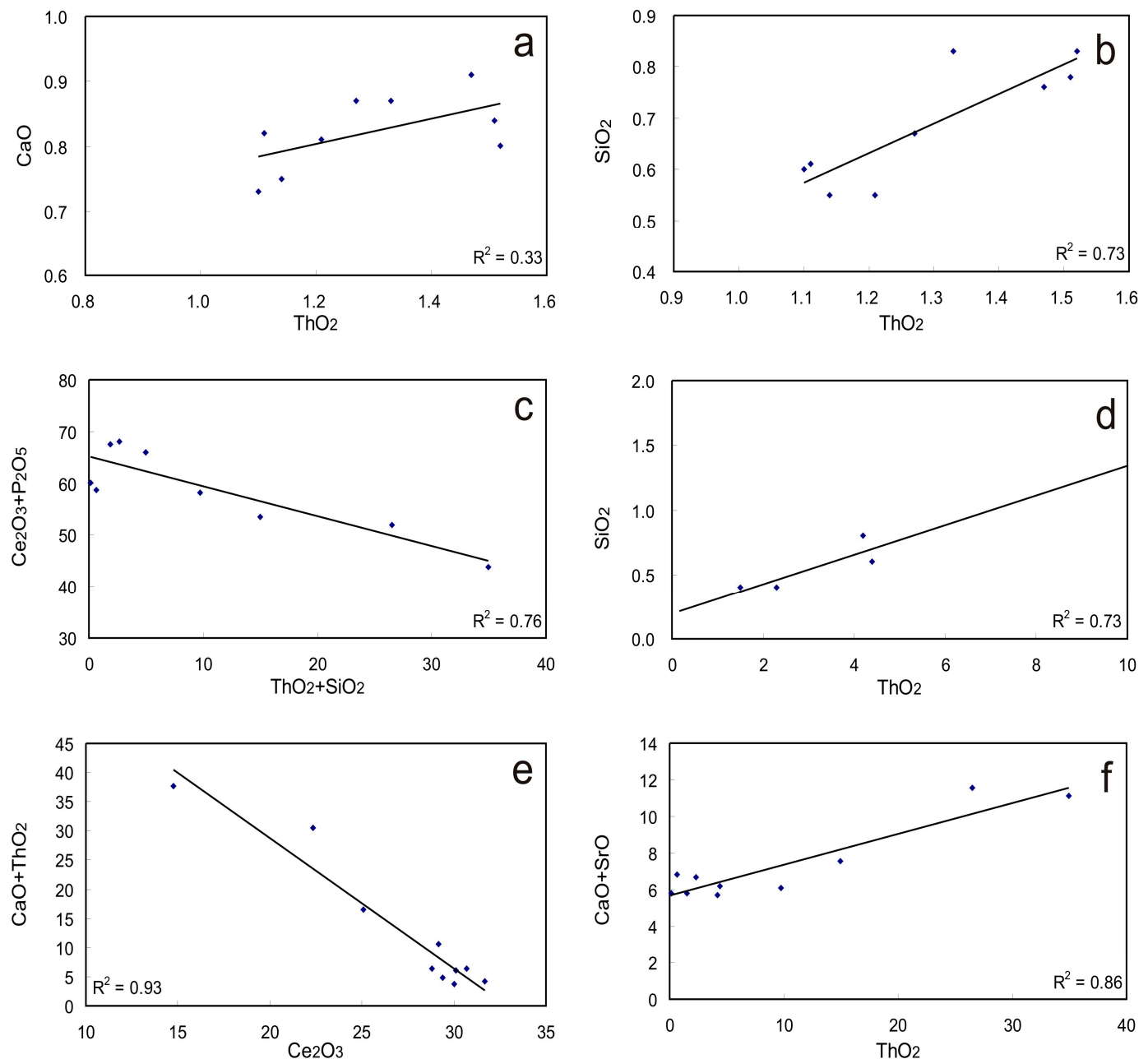

Figure 6. Substitution schemes for monazite from carbonatite related REE deposits. (a,b) dominated huttonite substitution scheme recorded for Naantali monazite; $(\mathbf{c}-\mathbf{f})$ huttonite and cheralite substitution for monazite from the Sokli and Lesnaya Varaka complex.

\section{Isotope Geochemistry}

Monazite, the dominant LREE phosphate, could ideally serve as a Sm-Nd isotopic indicator, widely used for Sm-Nd dating and Nd isotopic studies. Carbonatite related REE deposits are known to be characterized by large LREE to HREE fractionations, and display low $\mathrm{Sm} / \mathrm{Nd}$ ratios [3]. Monazite within carbonatite related REE deposits consists of lower $\mathrm{Sm} / \mathrm{Nd}$ when compared to those formed in other environments [2] (e.g., alkaline complex and pegmatite; Supplementary Materials Table S2). The average ${ }^{147} \mathrm{Sm} /{ }^{144} \mathrm{Nd}$ ratio is 0.065 for carbonatite related deposits, for alkaline complex and pegmatites it is 0.122 , and 0.091 for IOCG $=[2]$. The ${ }^{147} \mathrm{Sm} /{ }^{144} \mathrm{Nd}$ ratio for the monazite investigated in this study was composed of an average ratio of 0.071 , similar to that for carbonatite related REE deposits and distinctly lower than other rocks. This, in general, suggested that the Sm/Nd ratio in monazite had a correlation with the signature of their host (rocks/magma) source. However, highly variable ${ }^{147} \mathrm{Sm} /{ }^{144} \mathrm{Nd}$ ratios $(0.002-0.270)$ have been identified for monazite in those carbonatite related REE deposits (Supplementary Materials Table S2), which indicates that the Sm/Nd ratio for monazite crystallized from each specific complex is further controlled by the evolution of the magma, pressure, and temperature. LREE generally becomes more enriched through carbonatite magma differentiation, hence a lower $\mathrm{Sm} / \mathrm{Nd}$ ratio in monazite indicates crystallization from more evolved magma/fluid.

Since $\mathrm{Nd}$ is a major element in monazite (with a $\mathrm{Nd}_{2} \mathrm{O}_{3}$ composition of $\sim 10 \mathrm{wt} \%$ in average), monazite, especially in ore rocks, is definitely the dominant mineral, which reflects the Nd isotope 
composition of the carbonatite whole rock [14]. REEs are generally enriched in carbonatite magma and supply the nutrients for the crystallization of monazite regardless of the fluid or thermal trigger. Commonly, hydrothermal fluid serves as a trigger for the deposition of REE minerals including monazite and bastnasite in carbonatites. The hydrothermal fluid is released from surrounding country rocks or meteorite water, which is not as enriched in REEs compared to that of evolved carbonatite melts/liquids. Thus, though most monazite is secondary in origin, their Nd isotopic compositions still record the signature of their carbonatite magma source. The Sm-Nd isotopic system of monazite and whole rock for Bayan Obo dolomite marble have been intensely investigated [49]. Zhu et al. [49] showed that despite the variable ages from thermal disturbance, the monazite and whole rock shared the same original ${ }^{143} \mathrm{Nd} /{ }^{144} \mathrm{Nd}$ ratios at $1.3 \mathrm{Ga}$.

$\mathrm{SrO}$ content in monazite from carbonatite related ore also varies greatly, with the most enriched up to $8 \mathrm{wt} \%$ (e.g., Lesnaya Varaka; Supplementary Materials Table S2). In general, SrO content in monazite $(\sim 1.5 \mathrm{wt} \%)$ is not as high compared to $\mathrm{Nd}_{2} \mathrm{O}_{3}$. In the carbonatite samples, the dominate carbonate mineral (e.g., dolomite or calcite) probably hosts the $\mathrm{SrO}$, since the $\mathrm{Sr}$ abundance is comparable to, or even higher than, monazite, and they have larger modal compositions $(>50 \%)$. It has also been proposed that as most monazite occurs as a secondary phase in carbonatite related complexes, Sr isotopes may be unreliable as source signatures of the magma [20]. Furthermore, it is quite possible that some of the monazite might reflect signatures of the open-system fluid, which might contain some $\mathrm{Sr}$ (e.g., fluid evolved from limestone). As such, a combined $\mathrm{Sr}$ and $\mathrm{Nd}$ isotopic investigation of monazite could be useful to track the original magma source and secondary alteration.

\section{Geochronology}

Monazite has long been used as Th- $\mathrm{Pb}$ and $\mathrm{U}-\mathrm{Pb}$ chronometers in various environments, and recent developments of in-situ methods have enabled the examination of these chronometers in more detail $[50,51]$. Of note is that fluid-induced recrystallization constitutes an efficient way to reset monazite chronometers [52]. Though $\mathrm{U}-\mathrm{Pb}$ and $\mathrm{Th}-\mathrm{Pb}$ systematics can be highly disturbed, they may ultimately provide meaningful magmatic or fluid-alteration ages [45,53].

Monazite formed within carbonatite related deposits usually contains high $\mathrm{ThO}_{2}$ contents with relatively low $\mathrm{U}$ and $\mathrm{Pb}$ abundances $[18,21,54]$. Most of the age dating results use $\mathrm{Th}-\mathrm{Pb}$ ages due to the analytical limitations with low- $\mathrm{U}$ analyses, i.e., discordant $\mathrm{Pb} / \mathrm{U}$ and $\mathrm{Pb} / \mathrm{Th}$ dates have been identified for monazite with depleted U contents (e.g., Cummins Range monazite) [55]. Th released during monazite dissolution is probably incorporated into newly-formed overgrowth rims, which results in Th-rich and $\mathrm{Pb}$-depleted zones and gives younger ages [50-53]. The variable monazite ages (as observed by several investigations for Bayan Obo) record the younger metasomatic age rather than the mid-proterozoic formation age recorded by the Sm-Nd system $[49,56]$.

\section{Beneficiation of Monazite}

Rare earth mining of can be divided into three historic eras: (1) monazite-placer; (2) Mountain Pass; and (3) Bayan Obo. Both of the latter deposits are bastnasite dominated with associated monazite. Traditionally, the most important deposits for monazite extraction are beach sands and river placers, and are often processed as by-products of ilmenite, zircon, and cassiterite mining [27]. They are typically concentrated via initial high-capacity gravity separation steps to take advantage of the high specific gravity of monazite (greater than 5), whereas typical gangue minerals in these deposits have specific gravities less than 3.5 [4]. These are followed by additional gravity, magnetic, electrostatic and occasionally flotation separation steps [55]. These monazites are typically high in $\mathrm{ThO}_{2}(1-27 \mathrm{wt} \%)$ [57] with extremes consisting of pure huttonite $(79.21 \mathrm{wt} \%$; [46]), which are much higher compared to carbonatite related REE deposits (generally $<2 \mathrm{wt} \%$; Supplementary Materials Table S2).

Recently, monazite has been mined in supergene carbonatite complexes such as Mt. Weld in Australia, which is claimed to contain the highest grade known REE deposit in the world [58]. The Mt. Weld mine has a conventional open-pit operation and was concentrated in the first phase 
using flotation technology; the second phase was processed in the Lynas advanced materials plant in Malaysia, which possibly include steps of calcinations, caustic conversion, acid leaching, and solvent extraction [58].

Acid bake leach and alkaline bake/pug roast leach are efficient processing routes in extracting high percentages of REEs and actinides and have economic advantages [59]. Leach processing is not selective and usually requires a series of downstream separation techniques [59]. Organophosphorus extractants have been extensively employed in the extraction and separation of rare earth elements, and neutral phosphine oxide is the most widely used due to high stability, low aqueous solubility, and rapid phase disengagement $[60,61]$. For instance, recent studies have investigated the extraction and separation of $\mathrm{La}, \mathrm{Ce}, \mathrm{Pr}, \mathrm{Nd}, \mathrm{Sm}, \mathrm{Yb}$, and Y from monazite using CYANEX 923 in kerosene [59,62,63], and detailed recovery processing of REEs from monazite can be found in the work of Aly et al. [59]. The extraction process of radioactive elements of Th and U from monazite was investigated by El-Hefny et al. [62] and El-Nadi et al. [64]. Except for the extremely high Th-monazite, rarely-identified in carbonatite, most REE extraction from monazite in carbonatite-related deposits follow the processing described by Aly et al. [59]. Furthermore, Maes et al. [65] proposed a two-stage recovery strategy focused on the recovery of $\mathrm{Nd}$ and La from monazite that combined microbially based leaching with electro-chemical extraction. The radioactive element thorium and counter-ions phosphate and citrate were proven to effectively separate from REEs in the anolyte, which allows for the sustainable reuse of the leaching agent [41]. Currently, REEs have a low price in the global market, especially the LREEs. The price for $\mathrm{Nd}_{2} \mathrm{O}_{3}$ (USD\$38-40 kg-1) is much higher than $\mathrm{La}_{2} \mathrm{O}_{3}$ and $\mathrm{Ce}_{2} \mathrm{O}_{3}\left(\mathrm{US} \$ 2 \mathrm{~kg}^{-1}\right.$ ), and, even for $\mathrm{Nd}$, it is currently not sufficient to balance the power costs $\left(\$ 314 \mathrm{~kg}^{-1}\right.$ for $\left.\mathrm{Nd}\right)$ using environmentally-friendly technology to recover the REEs [65].

\section{Conclusions}

Monazite is one of the most important REE minerals for over 30 carbonatite related REE deposits worldwide, including the current open mines at Mt. Weld and Bayan Obo. These deposits are distributed widely across all continents except Antarctica. Monazite occurs as a primary crystal in carbonatite (though rare), and mostly presents as a secondary mineral phase that shows strong association with apatite. It can partially or completely replace apatite, or form thin or thick overgrowth apatite depending on the availability of REEs. Other mineral phases that usually crystallize with monazite include barite, xenotime, bastnasite, sulfide, quartz, and so on.

The chemical compositions of monazite display variable compositions, and Ce-monazite is the dominant solid solution in carbonatite related REE deposits. Most of the monazites display steep fractionation from $\mathrm{La}$ to $\mathrm{Lu}$ without $\mathrm{Eu}$ or $\mathrm{Ce}$ anomalies in the chondrite normalized REE patterns. They display a pivot point at $\mathrm{Ce}$, and $\mathrm{La}$ and $\mathrm{Nd}$ vary depending on availability. The other two dominant components are huttonite and cheratite that both contribute to the accommodation of Th. Some rare sulfur bearing monazite has also been identified with $\mathrm{SO}_{3}$ up to $4 \mathrm{wt} \% .{ }^{147} \mathrm{Sm} /{ }^{143} \mathrm{Nd}$ ratios with an average value of $\sim 0.071$ for monazite within carbonatite related ores were similar to their host rocks ( 0.065) and were the lowest compared to other REE deposits. Nd isotopic composition for monazite could be used to track the source, whereas $\mathrm{Sr}$ isotopic composition could possibly reflect some signature of the fluid source. $\mathrm{Th}-\mathrm{U}-\mathrm{Pb}$ age determination of monazite may also record variable thermal or metasomatic disturbances, and careful geochronological interpretation should be brought forward. $\mathrm{ThO}_{2}$ is the most difficult contamination in the beneficiation of monazite, though luckily, high $\mathrm{ThO}_{2}$ contents are rarely identified in carbonatite related deposits.

Supplementary Materials: The following are available online at www.mdpi.com/2079-9276/6/4/51/s1. Table S1: Description of monazite dominant carbonatite related REE deposits, Table S2: Chemical composition of monazite within carbonatite and associated alkaline rocks.

Acknowledgments: The authors would like to thank Hangyu Liu from the China University of Geosciences (Wuhan) for offering samples from Bayan Obo for investigation as well as Yuancan Ying, Jue Lu, and Fan Yang from the same institute for the data collection and constructive suggestions in preparation of this manuscript. 
This study is supported by the National Natural Science Foundation of China (No. 41402046, 41673035, 41530211), the Fundamental Research Funds for the Central Universities and the special fund from the State Key Laboratory of Geological Processes and Mineral Resources (No. MSFGPMR03-2).

Conflicts of Interest: The authors declare no conflict of interest.

\section{References}

1. Verplank, P.L. The role of fluids in the formation of rare earth element deposits. Procedia Earth Planet. Sci. 2017, 17, 758-761. [CrossRef]

2. Weng, Z.H.; Jowitt, S.M.; Mudd, G.M.; Haque, N. A detailed assessment of global rare earth element resources: Opportunities and challenges. Econ. Geol. 2015, 110, 1925-1952. [CrossRef]

3. Chakhmouradian, A.R.; Zaitsev, A.N. Rare earth mineralization in igneous rocks: Sources and processes. Elements 2012, 8, 347-354. [CrossRef]

4. Jordens, A.; Cheng, Y.P.; Waters, K.E. A review of the beneficiation of rare earth element bearing minerals. Miner. Eng. 2013, 41, 97-114. [CrossRef]

5. Jha, M.K.; Kumari, A.; Panda, R.; Kumar, J.R.; Yoo, K.; Lee, J.Y. Review on hydrometallurgical recovery of rare earth metals. Hydrometallurgy 2016, 165, 2-26. [CrossRef]

6. Mackay, D.A.R.; Simandl, G.J.; Ma, W.; Redfearn, M.; Gravel, J. Indicator mineral-based exploration for carbonatites and related specialty metal deposits-A QEMSCAN orientation survey, British Columbia, Canada. J. Geochem. Explor. 2016, 165, 159-173. [CrossRef]

7. Decheux, N.; Clavier, N.; Podor, R. Monazite as a promising long-term radioactive waste matrix: Benefits of high-structural flexibility and chemical durability. Am. Mineral. 2013, 98, 833-847. [CrossRef]

8. Mariano, A.N. Nature of Economic Mineralization in Carbonatites and Related Rocks. In Carbonatites: Genesis and Evolution; Unwin: London, UK, 1989.

9. Hurai, V.; Paquette, J.L.; Huraiova, M.; Slobodnik, M.; Hvozdara, P.; Siegfried, P.; Gajdosova, M.; Milovska, S. New insights into the origin of the Evate apatite-iron oxide-carbonate deposit, Northeastern Mozambique, constrained by mineralogy, textures, thermochronometry, and fluid inclusions. Ore Geol. Rev. 2017, 80, 1072-1091. [CrossRef]

10. Dill, H.G. A review of mineral resources in Malawi: With special reference to aluminium variation in mineral deposits. J. Afr. Earth Sci. 2007, 47, 153-173. [CrossRef]

11. Prokopyev, I.R.; Doroshkevich, A.G.; Ponomarchuk, A.V.; Sergeev, S.A. Mineralogy, age and genesis of apatite-dolomite ores at the Seligdar apatite deposit (Central Aldan, Russia). Ore Geol. Rev. 2017, 81, 296-308. [CrossRef]

12. Trofanenko, J.; William-Jones, A.E.; Simandl, G.J.; Migdisov, A.A. The nature and origin of the REE mineralization in the Wicheeda carbonatite, British Columbia, Canada. Econ. Geol. 2016, 111, 199-223. [CrossRef]

13. Liu, Y.; Zhu, Z.; Chen, C.; Zhang, S.; Sun, X.; Yang, Z.; Liang, W. Geochemical and mineralogical characteristics of weathered ore in the Dalucao REE deposit, Mianning-Dechang REE Belt, western Sichuan Province, southwestern China. Ore Geol. Rev. 2015, 71, 437-456. [CrossRef]

14. Kim, N.; Cheong, A.C.; Yi, K.; Jeong, Y.J.; Koh, S.M. Post-collisional carbonatite-hosted rare earth element mineralization in the Hongcheon area, central Gyeonggi massif, Korea: Ion microprobe monazite U-Th-Pb geochronology and Nd-Sr isotope geochemistry. Ore Geol. Rev. 2016, 79, 78-87. [CrossRef]

15. Ani, T.A.; Sarapaa, O. Geochemistry and mineral phases of REE in Jammi carbonatite veins and fenites, southern end of the Sokli complex, NE Finland. Geochem. Explor. Environ. Anal. 2013, 13, 217-224. [CrossRef]

16. Woodard, J.; Hetherignton, C.J. Carbonatite in a post-collisional tectonic setting: Geochronology and emplacement conditions at Naantali, SW Finland. Precambrian Res. 2014, 240, 94-107. [CrossRef]

17. Basu, S.K.; Bhattacharyya, T. Petrography and mineral chemistry of alkaline-carbonatite complex in Singhbum crustal province, Purulia region, eastern India. J. Geol. Soc. India 2014, 83, 54-70. [CrossRef]

18. Le Bas, M.J.; Ba-bttat, M.A.O.; Taylor, R.N.; Milton, J.A.; Windley, B.F.; Evins, P.M. The carbonatite-marble dykes of Abyan Province, Yemen Republic: The mixing of mantle and crustal carbonate materials revealed by isotope and trace element analysis. Mineral. Petrol. 2004, 82, 105-135. [CrossRef]

19. Liou, J.G.; Zhang, R.V.; Ernst, W.G.; Rumble, D.I.; Maruyama, S. High-pressure minerals from deeply subducted metamorphic rocks. Rev. Mineral. 1998, 37, 33-96. 
20. Wall, F.; Zaitsev, A.N. Rare earth minerals in Kola carbonatites. Phoscorites and Carbonatites from Mantle to Mine: The Key Example of the Kola Alkaline Province. Mineral. Soc. Ser. 2004, 10, 341-373.

21. Poletti, J.E.; Cottle, J.M.; Hagen-Peter, G.A.; Lackey, J.S. Petrochronological constraints on the origin of Mountain Pass ultrapotassic and carbonatite intrusive suite, California. J. Petrol. 2016, 57, 1555-1598. [CrossRef]

22. Decree, S.; Boulvais, P.; Tack, L.; Andre, L.; Baele, J.M. Fluorapatite in carbonatite-related phosphate deposits: The case of the Matongo carbonatite (Burundi). Miner. Deposita 2016, 51, 453-466. [CrossRef]

23. Lazareva, E.V.; Zhmodik, S.M.; Dobretsov, N.L. Main minerals of abnormally high-grade ores of the Tomtor deposit (Arctic Siberia). Russ. Geol. Geophys. 2015, 56, 844-873. [CrossRef]

24. Lottermoser, B.G. Rare-earth element mineralization within the Mt. Weld carbonatite laterite, Western Australia. Lithos 1990, 24, 151-167. [CrossRef]

25. De Toledo, M.C.M.; de Oliveira, S.M.B.; Fontan, F.; Ferrari, V.C.; de Parseval, P. Mineralogia, morfologia e cristaloquímica da monazita de Catalão I (GO, Brasil). Revista Brasileira de Geociências 2004, 34, 135-146.

26. Castor, S.B.; Hedrick, J.B. Rare earth elements. In Industrial Minerals Volume, 7th ed.; Society for Mining, Metallurgy and Exploration Littleton: Englewood, IL, USA, 2006; pp. 769-792.

27. Mariano, A.N.; Mariano, A. Rare earth mining and exploration in North America. Elements 2012, 8, 369-376. [CrossRef]

28. Ribeiro, C.C.; Brod, J.A.; Junqueira-Brod, T.C.; Gaspar, J.C.; Petrinovic, I.A. Mineralogical and field aspects of magma fragmentation deposits in a carbonate-phosphate magma chamber: Evidence from the Catalao I complex, Brazil. J. S. Am. Earth Sci. 2005, 18, 355-369. [CrossRef]

29. Chakhmouradian, A.R.; Mitchell, R.H. Lueshite, pyrochlore and monazite-(Ce) from apatite-dolomite carbonatite, Lesnaya Varaka complex, Kola Peninsula, Russia. Mineral. Mag. 1998, 62, 769-782. [CrossRef]

30. Levinson, A.A. A system of nomenclature for rare earth minerals. Am. Mineral. 1966, 51, 152-158.

31. Nickel, E.H.; Mandarino, J.A. Revised nomenclature for rare-earth-elements minerals. Procedures involving the IMA Commission on New Minerals and Mineral Names, and guidelines on mineral nomenclature. Am. Mineral. 1987, 72, 1031-1042.

32. Graeser, S.; Schwander, H. Gasparite-(Ce) and monazite-(Nd): Two new minerals to the monazite group from the Alps. Schweiz. Mineral. Petrogr. M. 1987, 67, 103-113.

33. Cressey, G.; Wall, F.; Cressey, B.A. Differential REE uptake by sector growth of monazite. Mineral. Mag. 1999, 63, 813-828. [CrossRef]

34. Kim, S.J.; Lee, H.K.; Yin, J.; Park, J.K. Chemistry and origin of monazites from carbonatite dikes in the Hongcheon-Jaeun district, Korea. J. Asian Earth Sci. 2005, 25, 57-67. [CrossRef]

35. Zhu, X.K.; O’Nions, R.K. Monazite chemical composition: Some implications for monazite geochrology. Mineral. Petrol. 1999, 137, 351-363. [CrossRef]

36. Le Bas, M.J.; Keller, J.; Tao, K.J.; Wall, F.; Williams, C.T.; Zhang, P.S. Carbonatite dykes at Bayan Obo, Inner Mongolia, China. Mineral. Petrol. 1992, 46, 195-228. [CrossRef]

37. Smith, M.P.; Henderson, P.; Campbell, L.S. Fractionation of the REE during hydrothermal processes: Constraints from the Bayan Obo Fe-REE-Nb deposit, Inner Mongolia, China. Geochim. Cosmochim. Acta 1999, 64, 3141-3160. [CrossRef]

38. Doroshkevich, A.G.; Ripp, G.; Viladkar, S.G.; Vladykin, N.V. The arshan REE carbonatites, Southwestern Transbaikalia, Russia: Mineralogy, Paragenesis and evolution. Can. Mineral. 2008. [CrossRef]

39. Rose, D. Brabantite, CaTh $[\mathrm{PO} 4]_{2}$, a new mineral of the monazite group. N. Jahrb. Mineral.-Monatshefte 1980, 6, 247-257.

40. Laurent, A.T.; Seydoux-Guillaume, A.M.; Duchene, S.; Bingen, B.; Bosse, V.; Datas, L. Sulphate incorporation in monazite lattice and dating the cycle of sulphur in metamorphic belts. Mineral. Petrol. 2016, 171, 94. [CrossRef]

41. Xu, C.; Kynicky, J.; Chakhmouradian, A.R.; Qi, L.; Song, W.L. A unique Mo deposit associated with carbonatites in the Qinling orogenic belt, central China. Lithos 2010, 118, 50-60. [CrossRef]

42. Enkhbayar, D.; Seo, J.; Choi, S.G.; Lee, Y.L.; Batmunkh, E. Mineral chemistry of REE-rich apatite and sulfur-rich monazite from the Mushgai Khudag, alkaline volcanic-plutonic complex, South Mongolia. Int. J. Geosci. 2016, 7, 20-31. [CrossRef] 
43. Wall, F.; Niku-paavola, V.N.; Story, C.; Muller, A.; Jeffries, T. Xenotime-(Y) from carbonatite dykes at Lofdal, Namibia: Unusually low LREE: HREE ratio in carbonatite, and the first dating of xenotime overgrowths on zircon. Can. Mineral. 2008. [CrossRef]

44. Forster, H.J. The chemical composition of REE-Y-Th-U-rich accessory minerals from peraluminous granites of the Erzgebirge-Fichtelgebirge region, Germany. Part I: The monazite-(Ce)—brabantite solid solution series. Am. Mineral. 1998, 83, 259-272. [CrossRef]

45. Förster, H.J.; Harlov, D.E.; Milke, R. Composition and Th-U-total Pb ages of huttonite and thorite from Gillespie's Beach, South Island, New Zealand. Can. Mineral. 2000, 38, 675-684. [CrossRef]

46. Bulakh, A.G.; Nesterov, A.R.; Zaitsev, A.N.; Pilipuk, A.N.; Wall, F.; Kirillov, A.S. Sulfur-containing monazite-(Ce) from late-stage mineral assemblages at the Kandaguba and Vuorijarvi carbonatite complexes, Kola Peninsula, Russia. N. Jahrb. Mineral.-Monatshefte 2000, 5, 217-233.

47. Doroshkevich, A.G.; Ripp, G.S.; Moore, K.R. Genesis of the Khaluta alkaline-basic Ba-Srcarbonatite complex (West Transbaikala, Russia). Mineral. Petrol. 2010, 98, 245-268. [CrossRef]

48. Williams, M.L.; Jercinovic, M.J.; Hetherington, C.J. Microprobe monazite geochronology: Understanding geologic processes by integrating composition and chronology. Annu. Rev. Earth Planet. Sci. 2007, 35, 137-175. [CrossRef]

49. Zhu, X.K.; Sun, J.; Pan, C.X. Sm-Nd isotopic constraints on rare-earth mineralization in the Bayan Obo ore deposit, Inner Mongolia, China. Ore Geol. Rev. 2015, 64, 543-553. [CrossRef]

50. Poitrasson, F.; Chenery, S.; Shepherd, T.J. Electron microprobe and LA-ICP-MS study of monazite hydrothermal alteration: Implications for $\mathrm{U}-\mathrm{Th}-\mathrm{Pb}$ geochronology and nuclear ceramics. Geochim. Cosmochim. Acta 2000, 64, 3283-3297. [CrossRef]

51. Bosse, V.; Boulvais, P.; Gautier, P. Fluid-induced disturbance of the monazite Th-Pb chronometer: In situ dating and element mapping in pegmatites from the Rhodope (Greece, Bulgaria). Chem. Geol. 2009, 261, 286-302.

52. Seydoux-Guillaume, A.M.; Paquette, J.L.; Wiedenbeck, M.; Montel, J.M.; Heinrich, W. Experimental resetting of the U-Th-Pb systems in monazite. Chem. Geol. 2002, 191, 165-181. [CrossRef]

53. Poitrasson, F.; Chenery, S.; Bland, D.J. Contrasted monazite hydrothermal alteration mechanisms and their geochemical implications. Earth Planet. Sci. Lett. 1996, 145, 79-96. [CrossRef]

54. Wang, J.; Tatsumoto, M.; Li, X.; Premo, W.R.; Chao, E.C.T. A precise ${ }^{232} \mathrm{Th}^{208}{ }^{2} \mathrm{~Pb}$ chronology of fine-grained monazite: age of the Bayan Obo REE-Fe-Nb ore deposit, China. Geochim. Cosmochim. Acta 1994, 58, 3155-3169. [CrossRef]

55. Downes, P.J.; Dunkley, D.J.; Fletcher, I.R.; McNaughton, N.J.; Rasmussen, B.; Jaques, A.L.; Verral, M.; Sweetapple, M.T. Zirconolite, zircon and monazite-(Ce) U-Th-Pb age constraints on the emplacement, deformation and alteration history of the Cummins Range carbonatite complex, Halls Creek Orogen, Kimberley region, Western Australia. Mineral. Petrol. 2016, 110, 199-222. [CrossRef]

56. Ferron, G.A. Estimation of the deposition of polydisperse hyroscpic aerosol-particles in the respiratory-track. J. Aerosol Sci. 1991, 6. [CrossRef]

57. Kettanah, Y.A.; Ismail, S.A. Heavy mineral concentrations in the sandstones of Amij formation with particular emphasis on the mineral chemistry and petrogenetic characteristics of monazite, western desert of Iraq. J. Afr. Earth Sci. 2016, 123, 350-369. [CrossRef]

58. Haque, N.; Hughes, A.; Lim, S.; Vernon, C. Rare earth elements: Overview of mining, mineralogy, uses, sustainability and environmental impact. Resources 2014, 3, 614-635. [CrossRef]

59. Aly, M.I.; Masry, B.A.; Gasser, M.S.; Khalifa, N.A.; Daoud, J.A. Extraction of Ce (IV), Yb (III) and Y (III) and recovery of some rare earth elements from Egyptian monazite using CYANEX 923 in kerosene. Int. J. Miner. Process. 2016, 153, 71-79. [CrossRef]

60. Rydberg, J.; Musikas, C.G. Principles and Practices of Solvent Extraction; Marcel Dekker Inc.: New York, NY, USA, 1992.

61. El-Hefny, N.E.; Daoud, J.A. Extraction and separation of thorium (IV) and praseodymium (III) with CYANEX 301 and CYANEX 302 from nitrate medium. J. Radioanal. Nucl. Chem. 2004, 261, 357-363. [CrossRef]

62. El-Hefny, N.E.; El-Nadi, Y.A.; Daoud, J.A. Extraction of lanthanum and samarium from nitrate medium by some commercial organophosphorus extractants. Solvent Extr. Ion Exch. 2007, 25, 1-16. 
63. Masry, B.A.; Aly, M.I.; Khalifa, N.A.; Zikry, A.A.F.; Gasser, M.S.; Daoud, J.A. Liquid-liquid extraction and separation of $\operatorname{Pr}$ (III), Nd (III), Sm (III) from nitric acid medium by CYANEX 923 in kerosene. Arab J. Nucl. Sci. Appl. 2015, 48, 1-16.

64. El-Nadi, Y.A.; Daoud, J.A.; Aly, H.F. Modified leaching and extraction of uranium from hydrous oxide cake of Egyptian monazite. Int. J. Miner. Process. 2005, 76, 101-110. [CrossRef]

65. Maes, S.; Zhuang, W.-Q.; Rabaey, K.; Alvarez-Cohen, L.; Hennebel, T. Concomitant leaching and electrochemical extraction of rare earth elements from monazite. Environ. Sci. Technol. 2017, 51, 1654-1661. [CrossRef] [PubMed]

(C) 2017 by the authors. Licensee MDPI, Basel, Switzerland. This article is an open access article distributed under the terms and conditions of the Creative Commons Attribution (CC BY) license (http://creativecommons.org/licenses/by/4.0/). 